\author{
(c) (1) (8) \\ Jurnal Pendidikan Dasar Indonesia is licensed under \\ A Creative Commons Attribution-Non Commercial 4.0 International License
}

\title{
Pengembangan Bahan Ajar Penjaskes Pokok Bahasan Teknik Dasar Renang Gaya Bebas Dengan Pendekatan Kontekstual Pada SisWa KelaS X Di SMK DAERAH Situbondo
}

\author{
${ }^{1)}$ Heldie Bramantha \\ 1)FKIP Unars Situbondo, Jawa Timur \\ Email: Heldiebramantha86@gmail.com
}

\begin{abstract}
Abstrak. Keberadaan Pendidikan Jasmani telah diakui oleh pemerintah dalam Undang-Undang Republik Indonesia No. 20 tahun 2003 tentang Sistem Pendidikan Nasional pasal 42 khususnya isi kurikulum pendidikan dasar dan menengah yang menetapkan pelajaran Pendidikan Jasmani sebagai mata pelajaran yang wajib diberikan di sekolah mulai tingkat SD sampai dengan SLTA. Maka guru Pendidikan jasmani harus mampu melakukan inovasi-inovasi yang membuat pembelajaran yang aktif, inovatif, kreatif, efektif dan menyenangkan agar siswa mudah untuk melakukan gerakangerakan yang anggap sulit. Pendekatan kontekstual ini diterapkan mengingat bahwa sejauh ini pendidikan masih didominasi oleh pandangan bahwa pengetahuan sebagai perangkat Uji coba produk ini digunakan untuk mengumpulkan data sebagai dasar untuk menetapkan tingkat kelayakan dari produk yang telah dihasilkan.dalam produk bagian ini hal yang harus diperhatikan adalah: (1) Desain uji coba, (2) subjek uji coba, (3) instrument pengumpulan data, (4) teknik analisis data. Berdasarkan analisis terhadap kebutuhan bahan ajar Penjaskes pokok bahasan teknik dasar renang gaya bebas dengan pendekatan kontekstual yang ditulis lengkap dan mudah dipahami. Berdasarkan dari hasil angket kebutuhan siswa dan guru, bahan aja ini akan berisi 3 bab, bab I: sejarah, bab II: hakekat renang, bab III:gerakan teknik dasar renang gaya bebas. Bahan ajar ini dikemas dengan dikemas dengan ukuran A4 dengan jumlah halaman 30 dan ukuran huruf 14. Nilai rata-rata yang diberian oleh guru terhadap prototype bahan ajar ini yaitu 86,25 dengan kategorisangat baik dan dari dosen ahli sebesar 74,25 dengan kategori baik. Setelah melakukan perbaikan, maka bahan ajar ini berisi 3 bab, bab I: mengenal renang, bab II: Gerakan teknik dasar renang, bab III:gerakan teknik dasar renang gaya bebas. Mengacu pada hasil penelitian tersebut, peneliti menyarankan agar guru membantu siswa dalam penggunaan bahan ajar ini agar dapat belajar Penjaskes pokok bahasan teknik dasar renang gaya bebas dengan baik. Selain itu, para peneliti lain disarankan agar melakukan pengembangan lebih lanjut terhadap bahan ajar Penjaskes pokok bahasan teknik dasar renang gaya bebas dengan pendekatan kontekstual untuk melengkapi kekurangan pada bahan ajar tersebut dan untuk menguji efektivitas penggunaan bahan ajar Penjaskes pokok bahasan teknik dasar renang gaya bebas dengan pendekatan kontekstual.
\end{abstract}

Kata Kunci: Bahan Ajar, Kontekstual, Renang Gaya Bebas.

\section{Pendahuluan}

Pendidikan Jasmani merupakan mata pelajaran yang memiliki kedudukan yang vital dalam pembangunan Sumber Daya Manusia (SDM). Keberadaan Pendidikan Jasmani telah diakui oleh pemerintah dalam Undang-Undang Republik Indonesia No. 20 tahun 2003 tentang Sistem Pendidikan Nasional pasal 42 khususnya isi kurikulum pendidikan dasar dan menengah yang menetapkan pelajaran Pendidikan Jasmani sebagai mata pelajaran yang wajib diberikan di sekolah mulai tingkat SD sampai dengan SLTA. Hal ini menunjukkan bahwa Pendidikan Jasmani telah menjadi bagian integral dari proses pendidikan. Pada intinya pendidikan jasmani sebuah pendidikan untuk mencapai tujuan berupa kemampuan kognitif, afektif dan psikomotor.

Siswa harus memahami dan aktif membangun pengetahuan baru dari pengalaman dan pengetahuan yang dimiliki sebelumnya dalam pembelajaran Penjaskes. Siswa tidak hanya bergantung pada "apa" yang diajarkan, tetapi juga bergantung pada "bagaimana" penjaskes itu diajarkan, atau bagaimana siswa belajar.

Modul dengan pendekatan kontekstual mungkin dapat mengaktifkan siswa dalam proses pembelajaran yaitu mengaitkan pembelajaran dengan pengetahuan awal yang telah dimiliki, mengaitkan pembelajaran dengan situasi lingkungan siswa, memotivasi siswa dengan menyediakan kegiatan penjaskes atau tugas- tugas penjaskes yang berhubungan dengan kehidupan sehari-hari, membantu 
siswa untuk mengembangkan teori dan hasil temuan, membantu siswa mengembangkan keterampilan proses dengan mencatat semua kegiatan yang dilakukan serta dapat menggali pengalaman siswa akan suatu konsep yang dipelajari melalui suatu kegiatan pembelajaran terutama pada materi teknik dasar renang gaya bebas.

Berdasarkan uraian di atas, peneliti tertarik untuk mengembangkan sebuah produk pendidikan berbentuk modul terkait kemampuan teknik dasar renang gaya bebas dengan pendekatan kontekstual. Ada kecenderungan dalam dunia pendidikan dewasa ini, bahwa anak akan belajar dengan baik jika lingkungan belajar dicipakan secara alamiah. Selain itu, pembelajaran akan bermakna jika anak mengalami sendiri apa yang dipelajarinya. Pendekatan kontekstual (Contextual Teaching and Learning) yang disingkat CTL adalah suatu pendekatan yang karakteristiknya memenuhi harapan tersebut.

Alasan bahan ajar ini dikaitkan dengan pendekatan konekstual, yaitu karena pendekatan ini merupakan salah satu pendekatan yang sesuai untuk mengembangkan sebuah modul. Dengan tujuh komponen yang ada pada pendekatan kontekstual maka akan dihasilkan modul yang berkualitas karena dapat memotivasi siswa untuk lebih aktif dalam kegiatan pembelajaran. Penyajian materi dengan menggunakan pendekatan kontekstual akan mempermudah siswa dalam memahami materi teknik dasar renang gaya bebas karena pengetahuan diperoeh dengan cara mengalami sendiri bukan menghafal. Untuk itulah maka penulis ingin meningkatkan kemampuan siswatersebut dengan mengembangkan bahan ajar teknik dasar renang gaya bebas dengan pendekatan kontekstual bagi siswa kelas X SMK Daerah Situbondo.

Tujuan penelitian ini yaitu mengembangkan bahan ajar pokok bahasan teknik dasar renang gaya bebas pada kelas $\mathrm{X}$ di SMK Daerah Situbondo, agar siswa lebih cepat dalam menguasai teknik dasar renang gaya bebas.

Penelitian ini menggunakan model pengembangan research and development (R\&D)yang dikemukakan oleh Sugiono (2010). Metode penelitian dan pengembangan adalah metode penelitian yang digunakan untuk menghasilkan produk tertentu dan menguji keefektifan produk tersebut (Sugiyono 2010:407). Metode penelitian ini merujuk pada model Borg \& Gall dengan sedikit penyesuaian sesuai konteks penelitian. Penelitian ini tujuan akhirnya adalah mengembangkan suatu produk yang dapat digunakan dalam pembelajaran. Adapun ruang lingkupnya adalah pengembangan bahan ajar teknik dasar renang gaya bebas dengan pendekatan kontekstual bagi siswa kelas $\mathrm{X}$ SMK, produk yang dihasilkan berupa bahan ajar teknik dasar renang gaya bebas dengan pendekatan kontekstual bagi siswa kelas X SMK.

\section{Metode PenElitian}

Langkah-langkah penyusunan dan pengembangan bahan ajar ini dilakukan dengan mengacu model pengembangan research and development (R\&D) yang dikemukakan oleh Sugiono. Tahap pertama diawali dengan melakukan Survei
Pendahuluan. Survey pendahuluan ini dilakukan mencari sumber pustaka dan hasil penelitian yang relevan, serta menganalisis kebutuhan akan bahan ajar teknik renang gaya bebas dengan pendekatan kontekstual bagi siswa SMK kelas $X$. tahap kedua dilakukan dengan awal pengembangan prototype dengan rincian kegiatan, penyusunan teks, format, bentuk bahan ajar menulis petunjuk sesuai hasil survey pendahuluan, penyusunan rancangan isi.

Tahap selanjutnya adalah Desain Produk dan deskripsi hasil, yang dilakukan dalam tahap ini adalah Merancang dan menyusun bahan ajar teknik dasar renng dengan pendekatan kontekstual bagi siswa SMK kelas X. Tahap terakhir yang dilakukan adalah revisi dan Perbaikan Desain, dalam tahap terakhir ini penulis melakukan proses memperbaiki kesalahan-kesalahan setelah melakukan validasi produk atau prototype dan mendeskripsikan penggunaan bahan ajar teknik dasar renang gaya bebas dengan pendekatan kontekstual bagi siswa SMK kelas X.

Dalam menyusun bahan ajar peneliti akan memperhatikan hasil angket kebutuhan siswa dan guru. Setelah dilakukan analisis hasil angket kebutuhan, diperoleh simpulan kebutuhan siswa dan guru mengenai aspek isi, penyajian materi, bahasa dan keterbacaan, dan grafika. Dari data tersebut, peneliti mulai merancang bahan ajar yang sesuai dengan kebutuhan siswa dan guru.

Bahan ajar yang akan disusun berbentuk buku. Isi buku disesuaikan dengan kriteria yang ada dalam penyusunan buku, sebagai berikut: (1) aspek isi, (2) aspek penyajian, (3) aspek bahasa dan keterbacaan, dan (4) aspek grafika.

Dalam penelitian ini terdapat dua kategori subjek uji coba. Pertama, subjek uji coba kebutuhan prototipe bahan ajar terdiri atas siswa dan guru. Kedua, subjek uji coba validasi prototipe yang akan menilai prototipe bahan ajar teknik dasar renang gaya bebas dengan pendekatan kontekstual. Instrument pengumpulan data yang digunakan dalam pengembangan bahan ajar teknik dasar renang gaya bebas pada siswa kelas $\mathrm{X}$ di SMK Daerah Situbondo menggunakan angket untuk analisis kebutuhan bahan ajar dan uji validasi.

\section{HASIL DAN PEMBAHASAN}

Berdasarkan analisis terhadap kebutuhan bahan ajar Penjaskes pokok bahasan teknik dasar renang gaya bebas dengan pendekatan kontekstual yang ditulis lengkap dan mudah dipahami. Berdasarkan dari hasil angket kebutuhan siswa dan guru, bahan aja ini akan berisi 3 bab, bab I: sejarah, bab II: hakekat renang, bab III:gerakan teknik dasar renang gaya bebas. Bahan ajar ini dikemas dengan dikemas dengan ukuran A4 dengan jumlah halaman 30 dan ukuran huruf 14.

Berdasarkan pemaparan hasil penilaian prototipe bahan ajar per aspek (penyajian materi, isi/materi, bahasa dan keterbacaan, dan grafika) oleh guru, bahan ajar yang dikembangkan peneliti sudah sesuai dengan kebutuhan siswa dan guru. Nilai rata-rata yang diperoleh adalah 86,25 dan termasuk dalam kategori sangat baik. 
Berdasarkan pemaparan hasil penilaian prototipe bahan ajar per aspek (penyajian materi, isi/materi, bahasa dan keterbacaan, dan grafika) oleh dosen ahli, bahan ajar yang dikembangkan peneliti sudah sesuai dengan kebutuhan siswa dan guru. Nilai rata-rata yang diperoleh adalah 74,25 dan termasuk dalam kategori baik.

Setelah melakukan uji validasi oleh tiga orang guru, yang terdiri dari 2 guru Penjaskes dan 1 guru bahasa Indonesia beserta dua orang dosen ahli, maka diperoleh hasil penilaian dan saran yang digunakan sebagai masukan atau bahan pertimbangan bagi perbaikan bahan ajar yang dikembangkan.

Perbaikan yang dilakukan terhadap prototipe bahan ajar penjaskes pokok bahasan renang gaya bebas dengan pendekatan kontekstual pada siswa kelas X di SMK Daerah Situbondo, yaitu (1) aspek penyajian materi, yaitu pengaturan kembali bab-bab yang disajikan, dan penambahan kolom catatan siswa, (2) aspek isi/materi, yaitu soal uraian berbentuk produk serta lebih menekankan lagi penerapan ketujuh komponen kontekstual, (3) aspek bahasa dan keterbacaan, yaitu pemilihan kata dan penggunaan bahasa lebih disederhanakan lagi, (4) aspek grafika, yaitu gambar dan tulisan pada sampul di tata ulang supaya lebih menarik lagi, tulisan "untuk Kelas X" pada sampul diganti menjadi "Kelas X", font pada judul diganti seluruhnya menggunakan times new roman, gambar ilustrasi gerakanteknik renang gaya bebas diperbanyak, ukuran huruf (font) dalam isi bahan ajar diganti menggunakan ukuran 12, dan jumlah halaman ditambah. Untuk saran secara umum yang diberikan adalah penambahan gambar dalam bahan ajar sehingga memenuhi proporsi ilustrasi, penataan kembali penulisan judul pada sampul, dan penataan kembali sistematika penyajian materi.

\section{KESIMPULAN}

Berdasarkan analisis terhadap kebutuhan bahan ajar Penjaskes pokok bahasan teknik dasar renang gaya bebas, siswa dan guru membutuhkan bahan ajar Penjaskes pokok bahasan teknik dasar renang gaya bebas yang ditulis dengan lengkap dan mudah dipahami oleh siswa. Selain itu, siswa dan guru menginginkan buku atau bahan ajar yang didesain dengan kemasan yang menarik, praktis, mudah dibawa ke mana-mana, dan sesuai dengan pemahaman siswa.

Berdasarkan hasil analisis angket kebutuhan siswa dan guru, penataan warna, gambar, maupun tulisan pada sampul depan buku ditempatkan pada posisi yang sesuai dan terlihat menarik, sedangkan untuk sampul belakang buku dicantumkan secara umum.

Bentuk buku bahan ajar Penjaskes pokok bahasan teknik dasar renang gaya bebas dikemas dengan ukuran A4 $210 \mathrm{x}$ $297 \mathrm{~mm}$. Jenis kertas cover buku bahan ajar ini menggunakan soft cover dan bagian isi buku menggunakan kertas HVS 70 gram. Isi dalam buku ini adalah materi Tentang pengenalan renang yang di dalamnya membahas hakekat dan sejarah renang, tentang gerakan teknik dasar renang, dan langkah-langlah melakukan teknik dasar renang gaya bebas. Selain materi, bahan ajar penjaskes pokok bahasan teknik dasar renang gaya bebas ini juga dilengkapi dengan rangkuman materi, latihan-latihan soal, tugas, dan evaluasi.

Nilai rata-rata yang diberikan oleh dua orang guru dan dua orang ahli terhadap prototipe bahan ajar penjaskes pokok bahasan teknik dasar renang gaya bebas dengan pendekatan kontekstual, yaitu (1) aspek penyajian materi sebesar 81,25 termasuk dalam kategori baik, (2) aspek isi/materi sebesar 81,25 termasuk dalam kategori baik, (3) aspek bahasa dan keterbacaan sebesar 77,5 termasuk dalam kategori baik, dan (4) aspek grafika sebesar 81 termasuk dalam kategori baik.

Setelah melakukan perbaikan-perbaikan berdasarkan hasil penilaian dan saran oleh guru dan ahli, maka bahan ajar penjaskes pokok bahasan teknik dasar renang gaya bebas dengan pendekatan kontekstual setelah perbaikan berisi materi Tentang pengenalan renang yang di dalamnya membahas hakekat dan sejarah renang, tentang gerakan teknik dasar renang, dan langkah-langlah melakukan teknik dasar renang gaya bebas. Seluruh materi akan disusun dalam 3 bab, bab I: mengenal renang, bab II: Gerakan teknik dasar renang, bab III:gerakan teknik dasar renang gaya bebas.

Bahasa dalam bahan ajar penjaskes pokok bahasan teknik dasar renang gaya bebas dengan pendekatan kontekstual ini disederhanakan lagi sesuai dengan tingkat pemahaman siswa SMA/SMK. Bentuk buku bahan ajar penjaskes pokok bahasan teknik dasar renang gaya bebas dengan pendekatan kontekstual ini dikemas dengan ukuran A4 dengan jumlah halaman 30 dan ukuran huruf 12. Sampul depan bahan ajar penjaskes pokok bahasan teknik dasar renang gaya bebas dengan pendekatan kontekstual ini berisi nama penulis, judul buku, penerbit, ilustrasi gambar seorang atlet renang. Untuk sampul belakang bahan ajar tercantum gambaran umum isi buku dengan ilustrasi seorang atlet sedang berenang.

\section{DAFTAR PUSTAKA}

Arikunto, Suharsimi. 2010. Prosedur penelitian suatu produk dan praktek. Jogjakarta: Renika Cipta

Bellawati, Tian dkk. 2003. Pengembangan bahan ajar. Jakarta Pusat: UT

Depdiknas. 2004. Pedoman Umum Pemilihan dan Pemanfaatan Bahan Ajar. Jakarta: Ditjen Dikdasmenum

Harianto, 2008. Perencanaan Pengajaran. Jakarta: Rineka Cipta.

Haller, David. 1992. Belajar Berenang. Bandung: CV. Pionir Jaya

Husni, Agustina, dkk.1997. Buku Pintar Olahraga. Jakarta. CV. Mawar Gempita

Lestari, Ika. 2013. Pengembangan Bahan Ajar Berbasis Kompetensi. Padang:Akademia.

Nur Hadi, Ibrahim. 2004. Pembelajaran Kontekstual dan Penerapannya. Surabaya:UNESA

Pannen, Paulina dan Purwanto.2001. Penulisan Bahan Ajar. Jakarta: Pusat Antar Universitas untuk Peningkatan dan Pengembangan Aktivitas Intruksional Ditjen Dikti Diknas

Prastowo, Andi. 2011. Panduan Kreatif Membuat Bahan Ajar Inovatif. Jogjakarta: Diva Press

Sugiyono. 2010. Metode Penelitian Pengembangan. Bandung: Alfabeta 